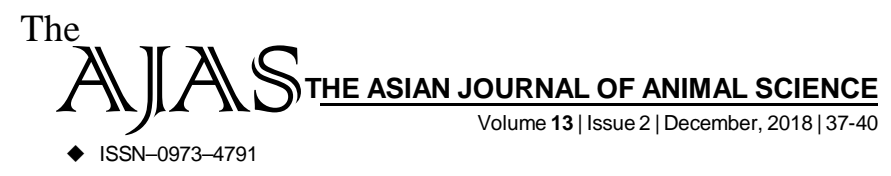

DOI : 10.15740/HAS/TAJAS/13.2/37-40 AA.

Visit us | www.researchjournal.co.in

RESEARCH ARTICLE.

\title{
Histological and histochemical studies on seminal vesicles in pre pubertal and pubertal ram
}

P.J. Kapadnis and P.N. Thakur. Th.............

Author for Corresponding -

\section{P.N. Thakur}

Department of Veterinary Anatomy and Histology

College of Veterinary and Animal

Sciences, Parbhani (M.S.)

India
ABSTRACT...... Histological features showed that the seminal vesicles consisted of capsule, interlobular septa, glandular alveoli, interstitial tissue and ducts. The glands were tubulo alveolar with alveoli lined by pseudostratified columnar epithelium comprising of ' $A$ ' and ' $B$ ' types of cells. The duct system comprised of central collecting sinus, interlobular ducts and main excretory duct. The glandular alveoli were more in number in pubertal than prepubertal ram. The micrometrical observations showed that values were more in pubertal than the prepubertal ram.

KEY WORDS...... Histology, Histochemistry, Seminal vesicles, Pubertal, Prepubrtal, Ram

HOW TO CITE THIS ARTICLE - Kapadnis, P.J. and Thakur, P.N. (2018). Histological and histochemical studies on seminal vesicles in pre pubertal and pubertal ram. Asian J. Animal Sci., 13(2): 37-40. DOI : 10.15740/HAS/TAJAS/13.2/37-40. Copyright@2018: HindAgri-Horticultural Society.

ARTICLE CHRONICLE - Received : 08.08.2018; Revised : 01.11.2018; Accepted : 12.11.2018 